\title{
Surgery for extensive, chronic aortic dissection: What about the elephant (trunks) in the room?
}

\author{
Leonard N. Girardi, MD
}

\author{
From the Department of Cardiothoracic Surgery, Weill Cornell Medicine, New York, NY. \\ Disclosures: Author has nothing to disclose with regard to commercial support. \\ Received for publication Nov 18, 2017; accepted for publication Dec 1, 2017; available ahead of print Jan 10, \\ 2018. \\ Address for reprints: Leonard N. Girardi, MD, Department of Cardiothoracic Surgery, Weill Cornell Medicine, \\ 525 E 68th St, M-404, New York, NY 10065 (E-mail: lngirard@med.cornell.edu). \\ J Thorac Cardiovasc Surg 2018;155:1923-4 \\ 0022-5223/\$36.00 \\ Copyright (C) 2017 by The American Association for Thoracic Surgery \\ https://doi.org/10.1016/j.jtcvs.2017.12.003
}

In this issue of the Journal, Kouchoukos and colleagues ${ }^{1}$ present their latest update on perioperative outcomes and long-term follow-up of patients with chronic, extensive aortic dissection who undergo 1-stage replacement of aneurysmal aorta through a bilateral "clamshell" thoracotomy. During a 21-year period, the senior author replaced the ascending aorta, arch, and varying lengths of the descending thoracic aorta in patients under deep hypothermic circulatory arrest, mostly patients who had previously undergone surgery for an acute type A dissection. The distal extent of descending thoracic aorta repair was dictated by an aortic diameter of $4.5 \mathrm{~cm}$ or less. All patients with larger aortas were relegated to 2-stage, open reconstruction. Despite the herculean efforts required to complete these operations successfully, the results were outstanding. Operative mortality (OM) was $2.5 \%$, with a gratifyingly low incidence $(1.2 \%)$ of both spinal cord injury and stroke. Durability was also reassuring, with a 93\% actuarial freedom from reoperation for aneurysmal growth of the contiguous distal aorta at 10 years. Morbidity, however, was not insignificant. The incidence of temporary neurologic dysfunction was $14 \%$, and significant ventilator support was necessary for nearly half of the 80 patients. Tracheostomy was ultimately required in $15 \%$ of cases, and substantial blood transfusions were required to obtain hemostasis. The mean hospital stay was 20.5 days. Without question, this operation works. Is this approach too aggressive, however, for the less than $30 \%$ of patients in need of downstream surgery after surviving acute type A repair? ${ }^{2}$ When surgery is necessary, how far distally should we proceed? Finally, is there any role for such an operation in an era of possible 1-stage endovascular repair (elephant 1$)$ ? Should anyone undergo a traditional 2-stage repair (elephant 2)?

Contemporary experiences with a frozen elephant trunk (FET) technique for extensive chronic dissection show its promise as a less invasive alternative to open 1-stage repair. In an earlier experience with 89 patients undergoing total arch and FET repair of chronic type A dissection, Sun and colleagues $^{3}$ reported an OM of only $1.1 \%$. The mean age

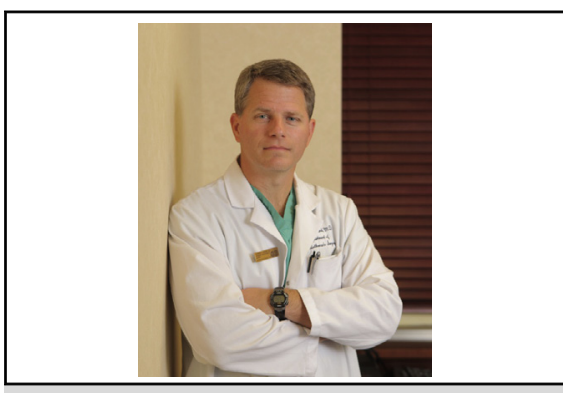

Leonard N. Girardi, MD

Central Message

One-stage repair of chronic aortic dissection provides reliable results. Availability of lessinvasive alternative techniques mandates thorough evaluation to determine what is best for each patient.

See Article page 1926.

of these patients was quite young, however, and none had a descending thoracic aorta segment longer than $5 \mathrm{~cm}$. A cohort of patients more representative of that seen in that in the report of Kouchoukos and colleagues ${ }^{1}$ tells a more cautionary tale. ${ }^{4}$ In 509 patients undergoing FET through a sternotomy and with antegrade cerebral perfusion, the OM was $15.9 \%$. When looking more closely at the 160 patients with either chronic type A or B dissections, the OM was $16.9 \%$ with a significant incidence of both spinal cord injury $(7.5 \%)$ and permanent neurologic deficit $(7.7 \%)$. Of the entire cohort, $26.5 \%$ had significant respiratory insufficiency develop, although the need for tracheostomy after this less-invasive alternative was not reported.

For those choosing a 2-stage technique, the outcomes are unfortunately more similar to that seen with FET than to that seen with the clamshell 1-stage repair. Etz and colleagues ${ }^{5}$ reported on 139 patients who completed both stages. The OM for those completing stage 2 was $7.5 \%$, in addition to the $6 \%$ OM seen for stage 1 . Spinal cord injury occurred in $2 \%$ and permanent neurologic deficit in $7 \%$ of those undergoing both operations. The need for tracheostomy was surprisingly low after stage $2(4.1 \%)$ but was offset by a higher than expected $13 \%$ incidence after the first-stage sternotomy. One further consideration is that for the 18 patients who did not come for their planned stage 2 surgery, 16 died within a mean of 5.4 months. 
It is clear that patients who need surgery for extensive, chronic aortic dissection incur substantial risk regardless of technique chosen. The future is promising for a lessinvasive option that may markedly reduce the need for additional operations. We should not, however, ignore the more invasive, but perhaps more reliable, elephant (trunk) being made to sit quietly in the corner. Patients should be given the option that is judged to have the best opportunity for success on the basis of their comorbidities and aortic anatomy.

\section{References}

1. Kouchoukos NT, Kulik A, Castner CF. Clinical outcomes and rates of aortic growth and reoperation following 1-stage repair of extensive chronic thoracic aortic dissection. J Thorac Cardiovasc Surg. 2018;155:1926-35.
2. Halstead JC, Meier M, Etz C, Spielvogel D, Bodian C, Wurm M, et al. The fate of the distal aorta after repair of acute type A aortic dissection. J Thorac Cardiovasc Surg. 2007; 133:127-35.

3. Sun LZ, Qi RD, Chang Q, Zhu JM, Liu YM, Yu CT, et al. Is total arch replacement combined with stented elephant trunk implantation justified for patients with chronic Stanford type A aortic dissection? J Thorac Cardiovasc Surg. 2009;138: $892-6$

4. Leontyev S, Tsagakis K, Pacini D, Di Bartolomeo R, Mohr FW, Weiss G, et al. Impact of clinical factors and surgical techniques on early outcomes of patients treated with frozen elephant trunk technique by using EVITA open stent-graft: results of a multicentre study. Eur J Cardiothorac Surg. 2016;49:660-6.

5. Etz CD, Plestis KA, Kari FA, Leuhr M, Bodian CA, Spielvogel D, et al. Staged repair of thoracic and thoracoabdominal aortic aneurysms using the elephant trunk technique: a consecutive series of 215 first stage and 120 complete repairs. Eur J Cardiothorac Surg. 2008;34:605-14; discussion 614-5.

Access to The Journal of Thoracic and Cardiovascular Surgery Online is reserved for print subscribers!

Full-text access to The Journal of Thoracic and Cardiovascular Surgery Online is available for all print subscribers. To activate your individual online subscription, please visit The Journal of Thoracic and Cardiovascular Surgery Online, point your browser to http://www.mosby.com/jtcvs, follow the prompts to activate your online access, and follow the instructions. To activate your account, you will need your subscriber account number, which you can find on your mailing label (note: the number of digits in your subscriber account number varies from 6 to 10). See the example below in which the subscriber account number has been circled:

\section{Sample mailing label}

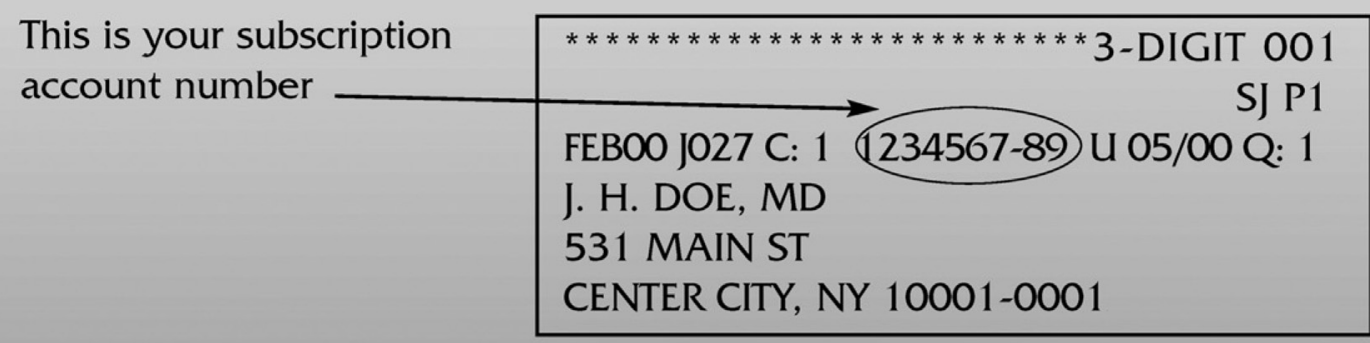

Personal subscriptions to The Journal of Thoracic and Cardiovascular Surgery Online are for individual use only and may not be transferred. Use of The Journal of Thoracic and Cardiovascular Surgery Online is subject to agreement to the terms and conditions as indicated online. 